\title{
AS TRANSFUSÕES SANGÜÍNEAS: O SANGUE E O SISTEMA DE CONHECIMENTO DAS PESSOAS
}

[The blood transfusion: the blood and the system of knowledge of people]

\author{
Salete Regina Maria D. Benetti* \\ Maria Helena Lenardt** \\ Fernanda Spiel Tuoto***
}

RESUMO: Trata-se de estudo teórico-reflexivo, no qual focalizo alguns aspectos relativos ao significado do sangue atribuídos pelas pessoas das diferentes culturas e religiões. Para tanto, foi realizado levantamento bibliográfico dos últimos 24 anos, período de 1980 a 2004.

PALAVRAS-CHAVE: Transfusão de sangue; cultura; significado; religião.

\section{CONSIDERAÇÕES INICIAIS}

Ao iniciar minha carreira como enfermeira, cheia de sonhos, com o intuito de trabalhar para modificar o quadro social "saúde $x$ pobreza $x$ doença", fui para uma cidade no interior do Rio Grande do Sul e trabalhei em um hospital de pequeno porte.

O primeiro desafio foi conquistar meu espaço como enfermeira, ou seja, o espaço do profissional enfermeiro, que até então era ocupado por "atendentes de enfermagem", pessoas sem nenhuma formação profissional, que iam aprendendo umas com as outras as atividades práticas e com abundante carência de embasamento científico. Percebia nas atitudes dos atendentes que estes verbalizavam, com freqüência, ansiedades e inseguranças. Diziamse ansiosos por estarem desejosos de saber mais,

\footnotetext{
*Docente da Universidade do Contestado, Campus Universitário de Canoinhas, SC. Discente do curso de Mestrado em Enfermagem da UFPR. Membro do GMPI.

**Docente da UFPR. Doutora em Filosofia da Enfermagem pela UFSC.

Líder do GMPI.

***Acadêmica do curso de graduação em Enfermagem da UFPR.

Bolsista de Iniciação Científica - CNPq. Membro do GMPI.
}

aproveitar as oportunidades para crescer profissionalmente e ter a chance de buscar a profissionalização. As demonstrações de insegurança estavam relacionadas ao medo de perderem o lugar (emprego) para outro profissional com formação superior, habilitado para exercer as atividades que até então vinham desenvolvendo.

Recém-formada e sem nenhuma experiência anterior no processo de trabalho do enfermeiro, parecia ser complicado ocupar o cargo de gerenciamento da equipe de enfermagem. Assumir a responsabilidade técnica pelos serviços de enfermagem, contando apenas com pessoal não habilitado, foi um desafio. Tentei promover pequenas mudanças estruturais e funcionais na instituição.

Nessa época, como responsável técnica pela equipe de enfermagem, alguns fatos foram marcantes, como a minha primeira doação sangüínea para uma criança com leucemia. A dificuldade de encontrar doadores, o desespero da família pela impotência em face da doença e a confiança e certeza deles referente à transfusão foram fatos determinantes que me levaram a fazer a doação sangüínea.

Logo após a transfusão, a criança foi a óbito. Isto chocou-me profundamente e despertou-me o interesse em estudar a respeito da temática.

Neste período, não foi possível realizar estudos referentes ao assunto, pois não havia banco de sangue, agência transfusional ou um hemocentro de referência. No acervo da biblioteca local, não se encontravam títulos que contemplassem o assunto, tampouco havia preocupação maior pelos profissionais em relação às transfusões, conforme preconiza o Ministério 
da Saúde no Programa Nacional de Sangue e Hemoderivados (PRO-SANGUE), apud Lisboa (1995), em seu Manual de Hemoterapia para serviços de coleta e transfusão de sangue.

Para os doadores de sangue da região, doar era um ato de amor, pois acreditavam ter vida saudável e estavam sempre dispostos a fazê-lo. A cada transfusão sentia-me insegura quanto aos cuidados, porquanto, além de conhecer pouco o assunto, havia a necessidade de conhecer melhor o ser humano, o ser doador e o ser paciente transfundido.

Tive a oportunidade de iniciar meus estudos, concernentes às transfusões sangüíneas, quando assumi a chefia do serviço de enfermagem em um hospital de médio porte, em Santa Catarina. Nessa instituição, observei que muitos doadores procuravam o serviço de hemoterapia com algumas queixas como: "minha pressão subiu após começar a doar sangue", "doar sangue faz a gente engordar", "tenho o sangue grosso e me aconselharam a doar para afinar", entre outras, 0 que na ocasião me levou a pensar que as suas inquietações estavam relacionadas com os seus sistemas de conhecimento.

Constatei também que os médicos freqüentemente prescreviam transfusão e alguns pacientes se submetiam sem questionamentos; no entanto, outros se negavam a serem transfundidos, e alguns até solicitavam "alta a pedido", interrompendo o tratamento. $\mathrm{Na}$ época, tentava "convencê-los" a se submeterem à transfusão, mesmo desconhecendo as causas da resistência, pois julgava que as doenças adquiridas por meio da transfusão ditavam tais rejeições.

Ao iniciar meus estudos independentes e tomar ciência da importância da eficiência nos mecanismos de controle dos testes e procedimentos laboratoriais, utilizados para a triagem e seleção do sangue e seus hemocomponentes, nas unidades hemoterápicas passei a questionar-me a respeito do sistema de conhecimento das pessoas sobre o sangue e o processo de transfusão sangüínea.

Como profissional enfermeira, sempre esteve presente em minha mente a certeza de que os enfermeiros devem estar comprometidos com as atividades educativas. As atividades educativas precisam significar aprendizagem, construção e modificação, para que possam promover cuidados mais efetivos. Promover atividades educativas, no processo de transfusão sangüínea, me parecia extremamente complicado, pois ainda não conseguia compreender as atitudes das pessoas.

Entretanto, compreender o comportamento das pessoas no processo de transfusão sangüínea, como: considerar o sangue a sua "salvação", indispensável para a "cura", medo de que ocorresse algum problema "durante a transfusão", ou, em outras ocasiões, negação da transfusão por problemas religiosos, era uma condição imposta da qual não poderia abrir mão, a fim de proporcionar-Ihes eficiência no cuidado prestado.

Nós, profissionais da área de saúde, sabemos que os cuidados contribuem para a qualidade do sangue a ser transfundido e para diminuir os riscos de efeitos colaterais em usuários, os quais podem ocorrer antes, durante ou após a transfusão (imediatos ou tardios), e que a deterioração e/ou contaminação do sangue humano coletado, bem como seus componentes e hemoderivados podem provocar contaminação de pacientes por doenças como a AIDS (Síndrome da Imunodeficiência Adquirida), hepatite, doença de Chagas e sífilis (MILLES, 1987).

Atualmente, a Enfermagem garante a qualidade da assistência quanto aos processos hemoterápicos; entretanto, não sabe o que pensam os doadores e os receptores, e quais os significados que eles atribuem. O que pensa a outra pessoa, muitas vezes, é incompatível com os conhecimentos que lhes foram inculcados pelo sistemas acadêmicos das ciências.

Os enfermeiros têm se destacado nos hemocentros e bancos de sangue nas atividades de: planejamento, execução, coordenação, supervisão e avaliação dos procedimentos hemoterápicos e de enfermagem nas unidades, visando a assegurar a qualidade do sangue e hemocomponentes/hemoderivados coletados e transfundidos.

É responsabilidade do enfermeiro realizar a triagem clínica, consulta de enfermagem, captação de doadores, proporcionar condições para o aprimoramento dos profissionais de enfermagem atuantes na área, participar da elaboração de programas de estágio, treinamento e desenvolvimento de profissionais de enfermagem nos diferentes níveis de formação, participar da 
definição da política de recursos humanos, da aquisição de material e da disposição da área física, necessários à assistência integral aos usuários, assistir, orientar e supervisionar o doador, durante o processo hemoterápico nas possíveis intercorrências, elaborando a prescrição da enfermagem necessária nas etapas do processo hemoterápico, avaliar e realizar a evolução do doador e do receptor junto a equipe multiprofissional, executar e/ou supervisionar a administração e monitoração da infusão de hemocomponentes e hemoderivados, detectando as eventuais reações adversas, registrar informações e dados estatísticos pertinentes ao doador e receptor, participar de programas de captação de doadores, desenvolver e participar de pesquisas relacionadas à hemoterapia e à hemotologia.

Julgo ser imperativo à Enfermagem discenir diferenças culturais, para melhor compreender as pessoas assistidas na sua essência, porquanto, como profissão, tem o dever de reconhecer e promover o cuidado/cuidar como fundamento de sua prática.

Neste artigo, tive como objetivo realizar um estudo teórico-reflexivo, embasado na literatura, no qual focalizo alguns aspectos relativos ao significado do sangue e das transfusões sangüíneas atribuídos pelas pessoas nas diferentes culturas e religiões.

\section{METODOLOGIA}

Trata-se de estudo teórico-reflexivo, para o qual foi realizada revisão bibliográfica em periódicos, livros, dissertações, sites, entre outros. O período consultado foi de 1980 a 2004 , utilizando-se as palavras chave: transfusão de sangue, cultura, significado e religião.

\section{REVENDO OS SIGNIFICADOS}

O homem, com sua propensão para criar símbolos, transforma inconscientemente objetos ou formas em símbolos e tem grande inclinação a explicar seus significados. Estes objetos ou formas podem ser representativos de algo que não é palpável, como define Chauí (1995): "Símbolo é alguma coisa que se apresenta no lugar de outra e presentifica algo que está ausente". Considerando que o indivíduo sofre influências, é instável, dinâmico, possuidor de um sistema de conhecimentos, e que cada nova informação vai sendo agregada ao seu sistema, podemos considerar o homem um ator social, pois atua nos cenários compostos pelos sistemas sociais $\mathrm{e}$ interpreta seus símbolos, embora não possa interferir sobre eles (GEERTZ, 1989).

Assim, como Geertz (1989), acredito que os símbolos emprestam valor e dão o teor das relações sociais e sentido às regras e normas que encadeiam o indivíduo à sua sociedade, sendo as lentes através das quais ele tem uma visão do mundo que o cerca.

As formas simbólicas produzem novos sentidos; não se limitam às definições conceituais, mas concretizam-se em formas culturalmente definidas, e manifestam a potencialidade criadora do homem. Os simbolismos, segundo Chauí (1995), surgem tanto para representar quanto para interpretar a realidade, dando-lhe sentido pela presença do humano no mundo.

Desta forma, tudo pode assumir significação simbólica: formas abstratas, objetos naturais ou fabricados pelo homem, de tal maneira que posso considerar que todo o cosmos é um símbolo em potencial.

O ser humano age em relação às coisas de acordo com os significados que elas tem para eles. Entende-se por "coisas" tudo o que o indivíduo pode observar no seu mundo. Os significados são produtos sociais que surgem da interação; portanto, não são meramente as coisas em si.

O ser humano usa os significados e as interpretações, adquiridos na sua vida social, uma vez que são frutos de um processo cumulativo que reflete o conhecimento e as experiências adquiridas pelas numerosas gerações que 0 antecedem. Todo o homem possui um sistema de conhecimento próprio, que sofre influências e que pode ser modificado, desta maneira, a interpretação simbólica ocorre de acordo com os diferentes intérpretes e as diferentes situações.

O homem atua nos cenários compostos pelos sistemas sociais e interpreta seus símbolos, embora não possa interferir sobre eles. A relação do homem com a natureza, com os outros homens e consigo mesmo nunca é imediata, mas sempre 
mediatizada pela representação que tem das coisas, idéias a partir das quais reage fisicamente ou mentalmente.

No meu cotidiano profissional, tenho observado que as pessoas idosas possuem seus próprios sistemas de significados, interpretando fatos e situações diferentemente dos jovens. Os idosos possuem significados próprios e hábitos de vida peculiares diferenciados. Estes hábitos tornam-se evidentes, a ponto de podermos dizer que estão cristalizados no seu cotidiano como parte significante da própria vida. O idoso preserva a sua cultura na sua maneira de pensar e conduzir a vida e procura transmití-la a seus descendentes de diversas maneiras, como na "introjeção pela educação dos indivíduos” (RODRIGUES, 1986, p. 11).

A condição humana não deriva da realização hipotética de instintos, mas para Aranha apud Lenardt (1996), resulta da assimilação dos modelos sociais, e a existência do homem se faz mediado pela cultura. A cultura é composta de elementos que emergem do processo de interação social e das experiências da vida social. Assim, penso que a cultura é adquirida pelo homem a partir do mundo que o rodeia; é o produto do indivíduo e da sociedade construído a partir de intermináveis gestos simbólicos.

Para Rodrigues (1986), "a cultura se constitui como um sistema de representação, uma atividade que consiste em estabelecer as rupturas, os contrastes e as distinções indispensáveis a constituição do sentido do mundo, das coisas e das relações sociais". Segundo Spradley (1980), cultura é "o conhecimento adquirido que as pessoas usam para interpretar sua experiência e gerar seu comportamento". Sob este ponto de vista a cultura envolve aquilo que as pessoas fazem, aquilo que sabem e ainda os objetos que elaboram e utilizam.

Quando me refiro à cultura, digo que nela e por ela os humanos atribuem a realidade significações novas, por meio das quais são capazes de se relacionar com o ausente, assim como a religião vincula o mundo profano (água, fogo, ar, animais, plantas, astros, pedras, metais, terra, humanos) com o mundo sagrado (as divindades que habitam a natureza).

A palavra religião vem do latim: religio, formada pelo prefixo re (outra vez, de novo) e o verbo ligare (ligar, unir, vincular). Assim, religião é um vínculo entre o profano e o sagrado, Chauí (1995). Para a autora, a religião pressupõe que, além do sentimento da diferença entre natural e sobrenatural, haja o sentimento da separação entre os humanos e o sagrado, mesmo que este habite os humanos e a natureza.

A religião organiza e separa o espaço da vida comum do espaço sagrado e Ihes dá qualidades culturais, contribui para o sistema de conhecimento dos homens e para a construção dos símbolos/ ritos e seus significados.

Segundo Bowker (1997, p.6), "as religiões unem as pessoas em práticas e crenças comuns; aproximam-nas em um mesmo objetivo de vida, e ser religioso significa tantas coisas para pessoas tão diferentes, que freqüentemente uns contradizem os outros".

Durante a minha prática profissional e em contato com algumas pessoas idosas, tenho mentalizado alguns trechos de conversas a respeito do significado do sangue e das transfusões sangüíneas. Para os idosos, é freqüente a expressão que o sangue significa vida e que sem sangue não há vida. Recebendo sangue ficam mais fortes!

Para as pessoas idosas, o sangue representa a vida, o que confere com o que se encontra nas literaturas pertinentes, as quais colocam que o sangue representa, como ícone, o símbolo da vida, o "fluxo vital". Segundo Franz (2003), "o sangue, correndo por nossas artérias e veias, sempre significou a continuidade do viver. A perda deste em demasia significa a perda da consciência, da respiração, dos movimentos e, por que não dizer, da vida. Cabe ainda asseverar que apenas nos vivos este sangue flui; nos mortos, tal sangue perde esta mobilidade e coagula".

O sangue está sempre presente na vida social. A ele se reconheceu, muitas vezes, um misterioso poder de catalisador social: mana. Segundo Rodrigues (1986), "os primitivos trabalhos da Etnologia deliciavam os seus leitores com narrativas concernentes à ingestão de sangue especialmente o humano". Porém, considerava que "a atitude diante do sangue é culturalmente variável", por exemplo: os Bororos (indígenas que se denominam boe que, em sua língua quer dizer gente, pessoa humana), são habitantes de várias aldeias em áreas descontínuas do vale do rio São Lourenço, 
no Mato Grosso, que se consideravam poluídos em alto grau ao mínimo contato com o sangue, enquanto os Nambiquaras (indígenas habitantes de aldeias espalhadas em áreas descontínuas, entre os campos cerrados da Chapada dos Parecis e as matas do vale do rio Guaporé, no Mato Grosso, e em Rondônia), consomem suas caças meio cruas e sanguinolentas.

Durante toda a história do homem, para Franz (2003), o sangue possui algum significado, na área religiosa e/ou relacionada com sacrifícios; por exemplo, na era pagã, os nossos antepassados utilizavam deste como sacrifício, provocando o seu derramamento para seus deuses. Até mesmo hoje, o sangue ainda tem essa importância. Basta nos referirmos à Igreja Católica, onde na Eucaristia temos como representação o corpo e o sangue de Cristo. Os gregos reconheciam o sangue como sustentáculo da vida. Os gladiadores romanos ingeriam sangue para ficarem mais fortes $e$ corajosos.

O sangue, às vezes, é considerado impuro, e às vezes cumpre em ritos de purificação a mesma função que a água. Em algumas ocasiões Ihe é atribuído valor regenerador e o vêem como princípio vital; noutras oportunidades, é tido como portador de destruição e de desgraça. Muitas sociedades, segundo Rodrigues (1986), "distinguem o sangue voluntariamente derramado, o sangue controlado, a que atribuem propriedades vivificantes e benéficas; sangue "bom", que serve para selar alianças sociais, de sangue "mau", que brota do corpo em desafio à vontade humana, que comove e amedronta".

Estas significações atribuídas ao sangue me permitem dizer que o indivíduo existe impregnado pelos símbolos. Transforma inconscientemente objetos ou formas em símbolos e lhes da expressões. O homem, segundo Geertz (1989), "é um animal amarrado às teias de significados que ele mesmo teceu". Assim, os significados atribuídos ao sangue refletem diretamente nos sistemas de significados atribuídos à transfusão sanguínea.

Não se pode falar em transfusão sangüínea sem resgatar um pouco da historia. Goff (1985), relata que a circulação sangüínea foi descoberta entre os anos 1620 e 1630, e a mais ilustre transfusão ocorreu em 1665, de um cão para outro; a partir daí, inúmeras transfusões foram realizadas, inicialmente usando sangue de animal em homem.

A transfusão, para as pessoas desta época, tinha o significado de "metamorfose" (mudança), também a possibilidade de curar doenças que confusamente associavam a fermentações anormais no sangue, como a loucura. Muitas experiências com transfusões entre seres humanos foram realizadas, algumas bem sucedidas, fazendo com que, na década de 1830 , a transfusão passasse a simbolizar o "progresso médico", pelo fato de, nos casos desesperados, ela fazer pender a balança para o bom lado, podendo restabelecer o equilíbrio das forças a favor da vida.

Hoje, quando se dispõe dos mais diversos recursos tecnológicos para garantir meios e eficiência nas transfusões, ainda se encontram pessoas que, impregnadas por significados religiosos ou culturais, não aceitam serem transfundidas, assim como as pessoas membros de determinadas seitas, como os das Testemunhas de Jeová que, por motivos religiosos, precisam abster-se de transfusões sangüíneas.

A base das estruturas Bíblicas, em que se apóiam os seguidores desta seita, está na seguinte passagem: Gen. 9:4, quando Jeová fez um pacto com Noé, depois do Dilúvio, no qual estava incluída esta ordem: "A carne com a vida nela, que é o sangue que está nela, não deveis comer". As pessoas membros da seita Testemunhas de Jeová consagram as suas vidas a Deus e sentem-se vinculadas à sua palavra e, com estes pontos em vista, elas decidem individualmente o seu caminho pessoal e assumem a responsabilidade pessoal pelos seus atos perante a Deus.

A Bíblia Sagrada declara que o sangue só pode ser usado corretamente no altar; nas outras situações, deve ser derramado no chão. Toda a prática médica moderna, envolvendo o uso do sangue, é objetável do ponto de vista Cristão. Por essa razão, considera-se pecado receber uma transfusão de sangue ou, em vez disso, a infusão de alguma fração do sangue para suster a vida de uma pessoa.

Segundo Haugland (2003), a proibição do sangue está baseada na afirmação de que uma transfusão é o mesmo que comer sangue; por isso, tornou-se gradualmente uma instituição das 
Testemunhas de Jeová. Existem ainda outras menções de proibição da utilização do sangue como alimento nas Escrituras Hebraicas (ou Velho Testamento). Neste caso, as citações fazem menção direta ao sangue como alimento, assim como:

[...] "pois a alma de todo tipo de carne é seu sangue pela alma nele. Por conseguinte, eu disse aos filhos de Israel: não deveis comer o sangue de qualquer tipo de carne, porque a alma de todo tipo de carne é seu sangue. Quem o comer será decepado [da vida]. 15 Quanto a qualquer alma que comer um corpo morto ou algo dilacerado por uma fera, quer seja natural quer residente forasteiro, neste caso terá de lavar suas vestes e banhar-se em água, e ele terá de ser impuro até à noitinha; e ele terá de ser limpo. 16 Mas, se não as lavar e se não banhar sua carne, então terá de responder pelo seu erro" [...].

Conforme citações anteriores, acredito que as restrições às transfusões sangüíneas ocorrem devido às interpretações, como, por exemplo: para os judeus, o sangue não deve ser ingerido (pela boca), (LEVÍTICO. 17: 14-16); para os integrantes da seita Testemunhas de Jeová, não é aceito por meio da transfusão, segundo Haugland (2003), e para os católicos não há restrições.

\section{CONSIDERAÇÕES FINAIS}

Neste artigo, focalizo alguns aspectos relativos ao significado do sangue e das transfusões sangüíneas. Identifico como fator preponderante de significado o aspecto religioso, porém se faz necessário um estudo mais detalhado sobre o sistema de significado das pessoas, para encontrar outras respostas aos questionamentos que surgem por ocasião das transfusões sangüíneas. Até mesmo o significado atribuído ao conhecimento religioso demanda coleta de outras informações e interpretações.

Após reflexões embasadas nas citações bíblicas e recortes das referências bibliográficas a respeito das pessoas membros da seita Testemunhas de Jeová, é possível dizer que os seus sistemas de significados são diferentes. Enquanto para os católicos o sangue representa vida e a transfusão sangüínea é considerada um benefício que não altera sua vida ou sua maneira de ser, para os Judeus o sangue, sendo a alma da pessoa, não pode ser ingerido (ou transfundido) sob pena de se ingerir a alma do outro ser; para os membros da seita Testemunhas de Jeová, ser transfundido tem o mesmo significado de comer sangue, sendo considerado pelas escrituras como pecado, e o indivíduo é chamado de impuro.

Este artigo teve a pretensão de realizar um estudo, no sentido de interpretar algumas influências culturais (aspectos religiosos) e os diversos significados atribuídos ao sangue e as transfusões sangüíneas. Espero contribuir para que os profissionais de enfermagem possam melhor compreender as diferenças culturais e conseqüentemente cuidar das pessoas, levando em consideração o seu sistema de conhecimentos e significações, pois segundo Erdmann (1996, p. 130): "o cuidado acontece nos seres, a partir deles, para eles e por meio deles, coexistindo na natureza e por onde suas estruturas podem ser pensadas".

Os profissionais da saúde são portadores de um sistema de conhecimento bem estabelecido, que serve como comparativo útil no reconhecimento de outros sistemas. O reconhecimento destes tem como finalidade promover entrosamento entre o profissional e a outra pessoa. Compreender e respeitar os sistemas de conhecimentos e de significações, proporcionam a valorização da pessoa como ser humano.

Acredito que a responsabilidade pela qualidade dos atendimentos prestados nos serviços de hemoterapia, na assistência ao doador/ receptor é de todos os profissionais que atuam neles; entretanto, para aqueles que estão em contato direto com o doador/receptor, exigem-se compromissos, além daqueles que se referem à qualidade técnica das transfusões sangüíneas.

Conhecer a complexidade de fenômenos culturais, os símbolos (culturais ou religiosos) e suas relações, dentro de um complexo sistema de significados, no meu entendimento, é condição imprescindível para compreender os sistemas de conhecimento e as atitudes das pessoas.

Interpretar os significados e, em especial, o simbolismo do sangue relacionado a transfusão sangüínea possibilitará, por meio da atuação profissional, a redução ou a minimização dos conflitos religiosos, culturais e sociais, respeitandose o ser humano e atuando-se na promoção, proteção e recuperação da saúde.

ABSTRACT: This is a theorical-reflexive in which I focus on some aspects relating the blood and the 
blood transfusion meanings for the people on different cultures and religious. For this, it was used collected bibliographic of the last 24 years, since 1980 to 2004.

KEY WORDS: Blood Transfusion; Culture; Meaning; Religion.

\section{REFERÊNCIAS}

1. BÍBLIA. Português. Bíblia Sagrada. Tradução: FIGUEIREDO, A. P. São Paulo: Difusão Cultural do Livro, 2000.

2. Levítico. Português. Bíblia Sagrada. Tradução: FIGUEIREDO, A. P. São Paulo: Difusão Cultural do Livro, 2000. Cap. 17, vers. 14-16

3. BOWKER, D. Para entender as religiões. São Paulo: Ática; 1997.

4. CHAUI, M. Convite à filosofia. São Paulo: Ática; 1995.

5. ERDMANN, A. L. Sistemas de cuidados de enfermagem. Pelotas: Universitária - UFPel, 1996.

6. FRANZ, R. V. A questão do sangue: o sangue e a vida , a lei e o amor. Disponível em: http:// www.vigiatorre.hpg.ig.com.br/sangue.htm Acesso em 16 fev. 2003.

7. GEERTZ, C. A interpretação das culturas. Rio de Janeiro: Livros Técnicos e Científicos, 1989.

8. GOFF, J. L. As doenças têm história. Lisboa: Terramar, 1985.

9. HAUGLAND, J. S. A proibição do sangue. Disponível em: http://www.geocities.com/Athens/ Academy/6040/proibicao.htm Acesso em 16 fev. 2003.

10. LENARDT, M. H. O vivenciar do cuidado cultural na situação cirúrgica. Curitiba, 1996. 144 f. Dissertação (Mestrado em Assistência de Enfermagem) - Rede de Pós-Graduação em Enfermagem - REPENSUL, Expansão Pólo I, Universidade Federal do Paraná.
11. LISBOA, A. C. Hemoterapia: manual para serviços de coleta e transfusão de sangue. Hemo Informativo. Recife, v 1, n 2, p. 6-7, abril, 1995.

12. MILLER, O. et al. Diagnóstico e terapêutica em medicina interna. Rio de Janeiro: Atheneu, 1987.

13. PACHECO, J. L. Práticas sociais na promoção da saúde do idoso. Arquivos de Geriatria e Gerontologia. Rev. Científica Nacional Ltda., v 1, n 2, p. 80-81, agosto, 1997.

14. RODRIGUES, J. C. Tabu do corpo. Rio de Janeiro: Dois pontos, 1986.

15. SPRADLEY, J. Participant observation. Orlando: Library of Congress, 1980.

16. ULLMAN, R. A. Antropologia: O homem e a cultura. Petrópolis: Vozes, 1991.
ENDEREÇO DAS AUTORAS: Rua Comendador Fontana, 50 - ap. 14 Curitiba/PR 80030-070 lenardthart@hotmail.com 